\title{
Erratum to: Generation of cell-type-specific gene mutations by expressing the sgRNA of the CRISPR system from the RNA polymerase II promoters
}

\author{
Jiaqiang Wang ${ }^{1}$, Xin $\mathrm{Li}^{1,2}$, Yanhua Zhao ${ }^{1}$, Jingyu $\mathrm{Li}^{1}$, Qi Zhou ${ }^{1,2 \bowtie}$, Zhonghua Liu $^{1 凶}$ \\ ${ }^{1}$ College of Life Sciences, Northeast Agricultural University, Harbin 150030, China \\ 2 State Key Laboratory of Reproductive Biology, Institute of Zoology, Chinese Academy of Sciences, Beijing 100101, China \\ $\triangle$ Correspondence: qzhou@ioz.ac.cn (Q. Zhou), liu086@126.com (Z. Liu)
}

\section{ERRATUM TO: PROTEIN CELL 2015, 6(9):689-692 DOI 10.1007/S13238-015-0169-X}

In the original publication of the article, the corresponding authors' e-mail addresses were missed inadvertently. The corresponding authors' details are provided in this erratum.

\section{OPEN ACCESS}

This article is distributed under the terms of the Creative Commons Attribution 4.0 International License (http://creativecommons.org/ licenses/by/4.0/), which permits unrestricted use, distribution, and reproduction in any medium, provided you give appropriate credit to the original author(s) and the source, provide a link to the Creative Commons license, and indicate if changes were made.

The online version of the original article can be found under doi:10.1007/s13238-015-0169-x. 